\title{
KARAKTERISTIK FISIK PAKAN IKAN APUNG NON-EKSTRUSI YANG DIBUAT MELALUI FERMENTASI Rhizopus oryzae
}

\section{Physical Characteristics of Non-Extruded Floating Fish Feed Produced through Rhizopus oryzae Fermentation}

\author{
Asep Badru Zaman ${ }^{1}$, Catur Sriherwanto ${ }^{2, *}$, Etyn Yunita ${ }^{1}$, Imam Suja'i ${ }^{2}$ \\ ${ }^{1}$ Dept. Biologi, Fakultas Sains dan Teknologi, Universitas Islam Negeri (UIN) Syarif Hidayatullah Jakarta \\ ${ }^{2}$ Bitechnology Laboratory, BPPT, Building 630 PUSPIPTEK Area, Tangerang Selatan, Banten 15314 \\ *E-mail: catur.sriherwanto@bppt.go.id
}

\begin{abstract}
To reduce the feed production cost of floating fish feed, an innovative method which is cheaper, easier, and simpler compared to the use of extruder machine is needed to provide buoyancy to fish feed. This research was conducted to determine the physical characteristics of floating fish feed prepared through fermention using Rhizopus oryzae on the mixed substrate consisting of commercial sinking fish feed, cassava bagasse, and Lemna minor. The resulting fermented feed was subsequently compared with commercial sinking fish feed in terms of its water stability, absorption, and floatability. The water stability curves of both feed types showed a similar pattern for 20 hours. Both decreased dramatically in the first 0.5 hours, from $100 \%$ to $81 \%$ for the fermented feed, and to $83 \%$ for the commercial feed. The shape of a 40-minute water absorption curve for both feed types was very similar. The fermented feed absorbed water nearly 4 times its initial dry weight, while commercial feed up to about twice as much as its initial dry weight. For three hours, both fermented and commercial floating pellets stayed afloat $100 \%$ without sinking. Thus, fermentation using R. oryzae deserves further development as an alternative way to provide buoyancy to fish feed.
\end{abstract}

Keywords: floatability, floating feed, sinking feed, water absorption, water stability

\begin{abstract}
ABSTRAK
Untuk menekan biaya produksi pakan ikan apung, diperlukan inovasi pengapungan pakan ikan yang lebih murah, mudah, dan sederhana dibandingkan dengan penggunaan mesin ekstruder. Penelitian ini dilakukan untuk mengetahui karakteristik fisik pakan apung hasil fermentasi menggunakan kapang Rhizopus oryzae pada substrat campuran pakan tenggelam komersial, onggok, dan Lemna minor. Pakan fermentasi ini lalu dibandingkan dengan pakan apung komersial dalam hal stabilitas dalam air, absorbsi air, dan daya apung. Stabilitas dalam air kedua jenis pakan memiliki pola yang mirip selama 20 jam. Stabilitas keduanya menurun drastis pada 0,5 jam pertama, dari $100 \%$ ke $81 \%$ untuk pakan apung fermentasi, dan ke $83 \%$ untuk pakan apung komersial. Bentuk kurva absorpsi air selama 40 menit untuk kedua jenis pakan sangatlah mirip. Pakan apung fermentasi menyerap air hampir 4 kali bobot kering awalnya, sedangkan pakan apung komersial hingga sekitar 2 kali bobot kering awalnya. Selama tiga jam, baik pakan apung fermentasi maupun komersial mengapung $100 \%$ tanpa tenggelam. Jadi, fermentasi menggunakan $R$. oryzae layak dikembangkan lebih lanjut sebagai cara pengapungan alternatif pakan ikan.
\end{abstract}

Kata Kunci: daya apung, daya serap air, stabilitas dalam air, pakan apung, pakan tenggelam 


\section{PENDAHULUAN}

Lebih dari $50 \%$ dari total biaya produksi budidaya ikan berasal dari pakan (Rana et al. 2009). Pakan ikan di Indonesia dibuat menggunakan bahan baku yang sebagian besarnya masih didatangkan dari negara lain sehingga berdampak pada mahalnya harga pakan (Rasidi dan Haryadi 2016). Tingginya harga pakan ikan inilah yang mendorong digulirkannya program Gerpari (Gerakan Pakan Ikan Mandiri) oleh Direktorat Pakan, Direktorat Jenderal Perikanan Budidaya, Kementerian Kelautan dan Perikanan agar kedaulatan pangan di sektor perikanan dapat diwujudkan, khususnya agar terciptanya kemandirian pakan dengan menggunakan potensi ketersediaan bahan baku pakan lokal (Dirjen Perikanan Budidaya 2016), dan dengan demikian biaya pembelian pakan pun bisa ditekan dan keuntungan pembudidaya ikan dapat ditingkatkan.

Namun pembuatan pakan mandiri oleh pelaku usaha sektor perikanan terkendala sejumlah faktor, di antaranya adalah kualitas fisik pakan yang mudah pecah dan larut dalam air sehingga cepat menurunkan kualitas air; serta pakan yang mudah tenggelam sebelum dikonsumsi ikan (Kurniawan dan Lestariadi 2017). Pakan yang tidak dimakan ikan akan mengotori kolam ikan, dan selanjutnya akan mengalami penguraian secara mikrobiologis yang menghabiskan sejumlah besar oksigen yang terlarut dalam air kolam tersebut. Selain itu proses ini menaikkan kadar amonia dan nitrit hingga konsentrasi yang dapat meracuni ikan dalam waktu singkat (Somerville et al. 2014). Karena itu, diperlukan teknologi pengapungan pakan tepat guna yang tidak memerlukan biaya investasi dan operasional semahal pembuatan pakan komersial skala industri besar yang melibatkan proses ekstrusi menggunakan mesin ekstruder.

Metode non-ekstrusi ini sebenarnya pernah dilakukan sebelumnya menggunakan khamir Saccharomyces cerevisiae. Namun proses ini masih belum praktis karena masih memerlukan pengetahuan dan ketrampilan khusus tentang penambahan zat pengikat (binding agent), serta dibutuhkan tahapan penggorengan dalam minyak (deep frying) yang membutuhkan energi panas, minyak goreng, dan fasilitas penggorengan (Saputra 2016; Lindasari 2017).
Mempertimbangkan kondisi tersebut, metode lain yang jauh lebih praktis dan sederhana dalam pembuatan pakan ikan apung sangat diperlukan. Laboratorium Bioteknologi Pakan, Balai BioteknologiBPPT, kawasan PUSPIPTEK, Tangerang Selatan, telah mengembangkan metode pengapungan pakan ikan fermentatif menggunakan Rhizopus sp. (Sriherwanto et al. 2017; Leiskayanti et al. 2017). Fermentasi ini tidak membutuhkan sterilisasi alat maupun bahan, tanpa mempertimbangkan jenis serta komposisi zat pengikat (binder), dilakukan secara non-ekstrusi atau tanpa menggunakan mesin pembuat pakan apung (ekstruder), dan tanpa tahapan deep frying sehingga lebih hemat energi dan jauh lebih praktis. Penelitian ini dilakukan dalam rangka mengetahui karakteristik fisik pakan apung hasil fermentasi menggunakan kapang $R$. oryzae pada substrat yang merupakan campuran dari pakan komersial tenggelam, onggok dan gulma bebek (Lemna minor). Sifat fisik yang diuji meliputi absorpsi air (water absorption), stabilitas dalam air (water stability), dan daya apung (floatability).

\section{BAHAN DAN METODE}

\section{Waktu dan lokasi penelitian}

Penelitian dilakukan pada bulan Januari-September 2016 di Laboratorium Bioteknologi Pakan, Balai BioteknologiBPPT, Setu, Tangerang Selatan, Banten. Penelitian ini menggunakan metode komparatif dengan 2 sampel yang berbeda: pakan apung komersial Hi-Pro-Vite 781 (PT. Central Proteina Prima Tbk dengan kandungan protein, lemak, dan serat masing-masing sekitar $31-33 \%$, 4-6\%, dan $3-5 \%)$ sebagai kontrol dan pakan apung fermentasi yang dibuat dalam penelitian ini. Penelitian ini meliputi proses pembuatan pakan ikan fermentasi, pengujian karakteristik fisik pakan fermentasi yang meliputi stabilitas (keutuhan dan kekokohan) dalam air, absorpsi (daya serap) air, dan daya apung .

\section{Fermentasi pakan}

Inokulum ragi tempe yang mengandung $R$. oryzae $1 \mathrm{~g}\left(10^{5}-10^{6} \mathrm{cfu} / \mathrm{g}\right)$ dicampurkan dengan $50 \mathrm{~g}$ substrat yang merupakan campuran dari onggok singkong $30 \mathrm{~g}$, pakan komersial tenggelam P99 (PT. Central Proteina Prima Tbk) 15 g, gulma 
bebek (L. minor) segar $5 \mathrm{~g}$. Setelah diaduk merata, sebanyak $40 \mathrm{~mL}$ larutan mineral yang mengandung $\mathrm{KH}_{2} \mathrm{PO}_{4}(2,6 \mathrm{~g} / \mathrm{L})$, urea (2 $\mathrm{g} / \mathrm{L})$, dan $\left(\mathrm{NH}_{4}\right)_{2} \mathrm{SO}_{4}(8,1 \mathrm{~g} / \mathrm{L})$ ditambahkan, diaduk lagi hingga merata. Campuran tersebut lalu ditempatkan ke dalam cawan petri kaca (diameter $9 \mathrm{~cm}$, tebal $1 \mathrm{~cm}$ ), diinkubasi pada suhu $28-30^{\circ} \mathrm{C}$ (suhu ruang) selama 40 jam. Pakan hasil fermentasi diiris menggunakan cutter dengan ukuran 0,5 $\times$ $0,5 \mathrm{~cm}$ pada kertas grafik, lalu dikeringkan di dalam oven bersuhu $50^{\circ} \mathrm{C}$ selama 24 jam.

\section{Uji stabilitas dalam air}

Menggunakan metode Misra et al. (2002), stabilitas dalam air atau kekokohan dan kekompakan dalam air diukur dengan menempatkan 2-3 g sampel dalam saringan teh plastik berukuran \pm 200 mesh (Erizal et al. 2016). Sampel dan saringan ini lalu direndam dalam gelas beaker berisi air 500 $\mathrm{mL}$, diberi gelembung udara $3,5 \mathrm{~L} /$ menit menggunakan aerator akuarium (Luckiness, L828, Cina). Perendaman dilakukan selama $1 / 2,1,2,4,10$, dan 20 jam. Sampel yang telah menyerap air ditiriskan, lalu dioven selama 24 jam pada suhu $60^{\circ} \mathrm{C}$ hingga kering. Stabilitas dalam air sampel ditentukan menggunakan rumus:

$$
\text { Stabilitas dalam air }(\%)=\frac{D W_{\mathrm{t}}}{D W_{\mathrm{o}}} \times 100
$$

dimana:

$\mathrm{DW}_{t}$ : berat kering sesudah perendaman $(\mathrm{g})$ $\mathrm{DW}_{o}$ : berat kering sebelum perendaman $(\mathrm{g})$

\section{Uji absorpsi Air}

Uji ini memiliki prosedur sebagaimana uji stabilitas dalam air, bedanya setelah perendaman selama $1,3,5,10,20$ dan 40 menit, sampel ditimbang dalam keadaan basah tanpa pengeringan terlebih dahulu. Absorpsi air dihitung menggunakan rumus berikut (Misra et al. 2002) :

$$
\text { Absorpsi air }(\%)=\frac{W W_{t}-D W_{o}}{D W_{o}} \times 100
$$

dimana:

$\mathrm{WW}_{t}$ : berat basah setelah direndam air $(\mathrm{g})$ $\mathrm{DW}_{\mathrm{o}}$ : berat kering sebelum direndam air $(\mathrm{g})$

\section{Uji daya apung}

Daya apung diukur menggunakan metode Cruz et al. (2015) yang telah dimodifikasi, dan dilakukan dalam kondisi tanpa aerator. Sebanyak 10 butir pakan dijatuhkan ke dalam gelas beaker $500 \mathrm{~mL}$ yang berisi air $400 \mathrm{~mL}$. Jumlah sampel yang masih mengapung dicatat dalam rentang waktu tertentu, dimulai pada menit ke-0 hingga menit ke-180. Rumus daya apung:

$$
\text { Daya apung }(\%)=\frac{F_{f}}{F_{i}} \times 100
$$

dimana:

$\mathrm{F}_{f}: \quad$ sisa sampel yang mengapung

$F_{i}: \quad$ jumlah awal sampel (10 butir)

\section{Analisis data}

Data hasil penelitian disajikan grafik yang bersifat komparatif. Analisis data hasil pengujian fisik dilakukan secara deskriptif serta analisis statistik parametrik (Independent Sample t-test) untuk melihat perbedaan nyata kedua sampel.

\section{HASIL DAN BAHASAN}

\section{Pengamatan fisik pakan fermentasi}

Pencampuran tepung onggok (Gambar 1a), L. minor (Gambar 1b), pakan tenggelam komersial (Gambar 1c), dan larutan mineral menghasilkan substrat campuran berupa butiran-butiran basah yang terpisah satu sama lain dan tidak rekat dengan warna dominan coklat. Teksturnya mirip seperti dedak padi basah namun tidak berair (Gambar 1d). Setelah fermentasi menggunakan $R$. oryzae, butiran substrat yang awalnya terpisah tersebut (Gambar 1d) di akhir fermentasi berubah menjadi satu kesatuan padatan yang menyerupai bentuk cawan petri. Satu butiran substrat dengan yang lainnya diikat oleh jalinan miselia jamur sehingga membentuk tekstur seperti tempe kedelai dan kenyal seperti keju (Gambar 1e).

Saat penyiapan bahan baku komponen pakan, tidak ada pertimbangan penambahan komponen bahan pengikat dan perakat khusus, atau perlakuan mekanis dan termal yang sengaja dilakukan untuk merekatkan dan menyatukan substrat yang bertekstur butiran terpisah tersebut. Namun sesudah fermentasi, butiran-butiran substrat 

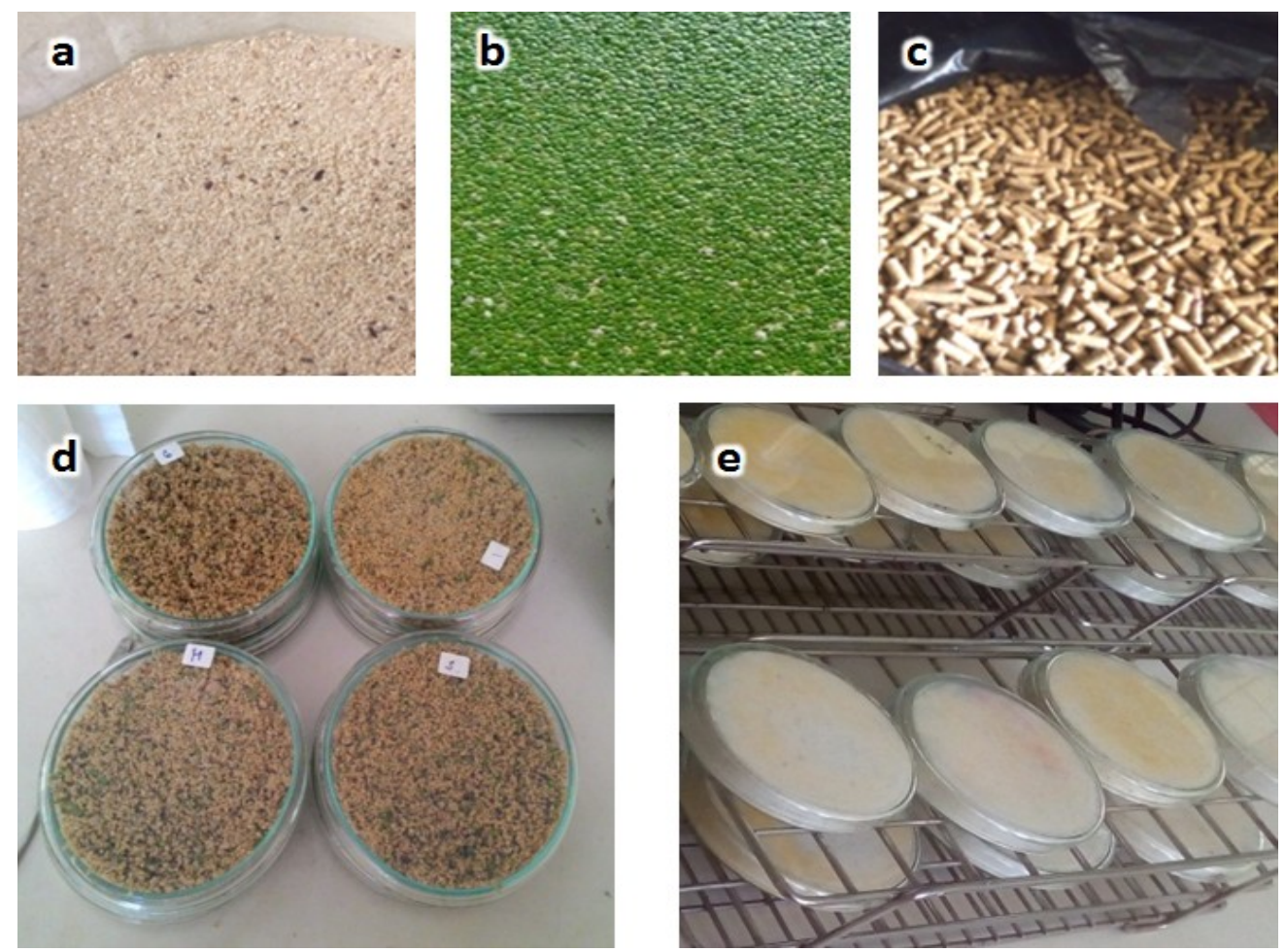

Gambar 1. Bahan pakan onggok (a), L. minor (b), pakan tenggelam komersial (c), dicampur dengan larutan mineral menghasilkan substrat campuran (d) yang, setelah difermentasi oleh $R$. oryzae, membentuk tekstur menyerupai tempe kedelai (e).

tersatukan membentuk satu kesatuan tekstur yang padat, kompak, dan kokoh. Hal ini menunjukkan bahwa miselia $R$. oryzae mampu menggantikan peran zat perekat dan pengikat yang biasanya ditambahkan dalam pembuatan pakan ikan bentuk pelet yang bahan baku awalnya berupa tepung halus. Prosedur mekanis dan termal yang biasa digunakan untuk memunculkan kekompakan, kekokohan, dan daya apung pada pelet juga tidak diperlukan dalam fermentasi ini.

Pakan apung fermentasi dan pakan apung komersial memiliki sejumlah perbedaan fisik (Gambar 2). Pakan apung komersial memiliki warna coklat gelap sedangkan pakan apung fermentasi berwarna lebih muda dan terang. Warna coklat gelap pada pakan apung komersial kemungkinan disebabkan oleh reaksi Maillard, yakni reaksi antara asam amino dengan gula pereduksi pada suhu tinggi (lebih dari $100^{\circ} \mathrm{C}$ ) pada proses ekstrusi (Ljøkjel et al. 2004; Von Rooijen 2016). Hal ini tidak terjadi pada fermentasi pakan yang menggunakan suhu ruangan, yakni sekitar $28-30^{\circ} \mathrm{C}$. Pembentukan miselia putih kapang Rhizopus justru menjadikan pakan fermentasi berubah warna menjadi lebih muda dan keputihan. Pakan fermentasi diperkecil dengan pengirisan pisau cutter hingga berbentuk balok berukuran panjang $\times$ lebar $\times$ tinggi sekitar $5 \times 5 \times 10 \mathrm{~mm}$, sedangkan pakan apung komersial hampir menyerupai bentuk bulat bola dengan garis tengah sekitar $4 \mathrm{~mm}$. Berbeda dengan pakan tenggelam komersial yang tidak dapat mengapung, pakan fermentasi ini memiliki daya apung yang baik (Gambar 3).

\section{Stabilitas dalam air}

Stabilitas dalam air kedua jenis pakan memiliki pola yang sama (Gambar 4) selama 20 jam, dimana keduanya mengalami penurunan drastis pada 0,5 jam pertama yaitu dari $100 \%$ turun ke $83 \%$ untuk pakan apung komersial dan $81 \%$ untuk pakan apung fermentasi. Antara jam ke-0,5 hingga jam ke-10, pakan apung komersial memperlihatkan nilai stabilitas dalam air yang lebih baik dari pakan apung fermentasi, terutama pada jam ke- 2 dimana selisihnya terbesarnya mencapai $4,45 \%$. Secara umum, adanya selisih yang tidak terlalu besar selama 20 jam perendaman dalam air ini menunjukkan bahwa stabilitas dalam air 


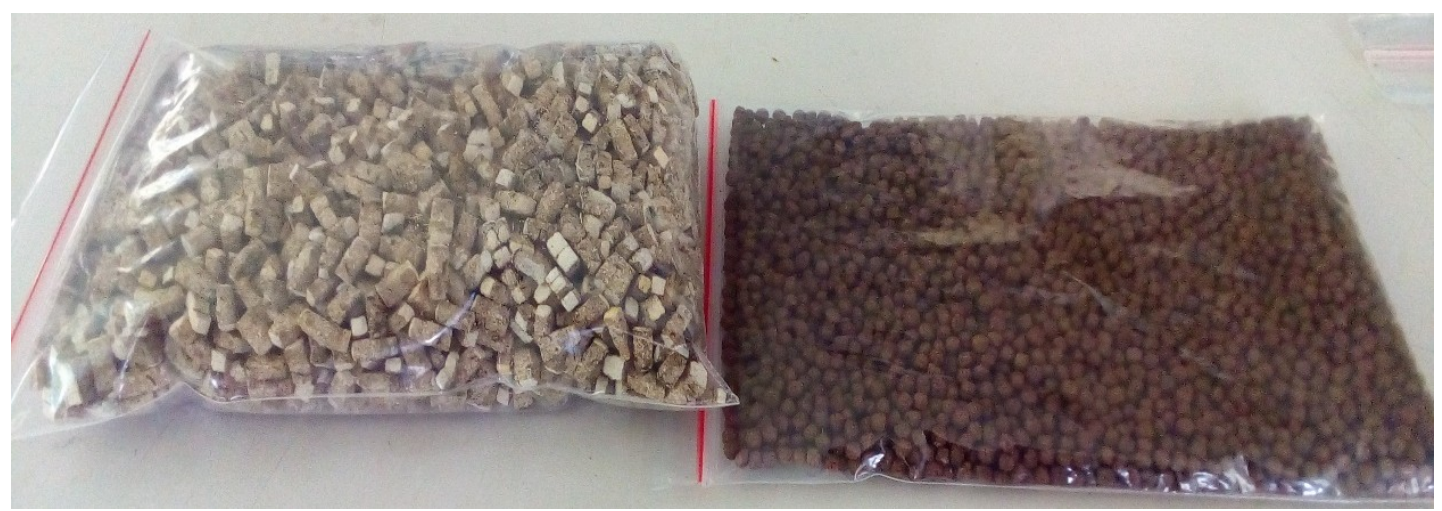

Gambar 2. Penampilan fisik pakan apung fermentasi (kiri) dan pakan apung komersial (kanan) dalam kemasan dengan berat masing-masing $100 \mathrm{~g}$
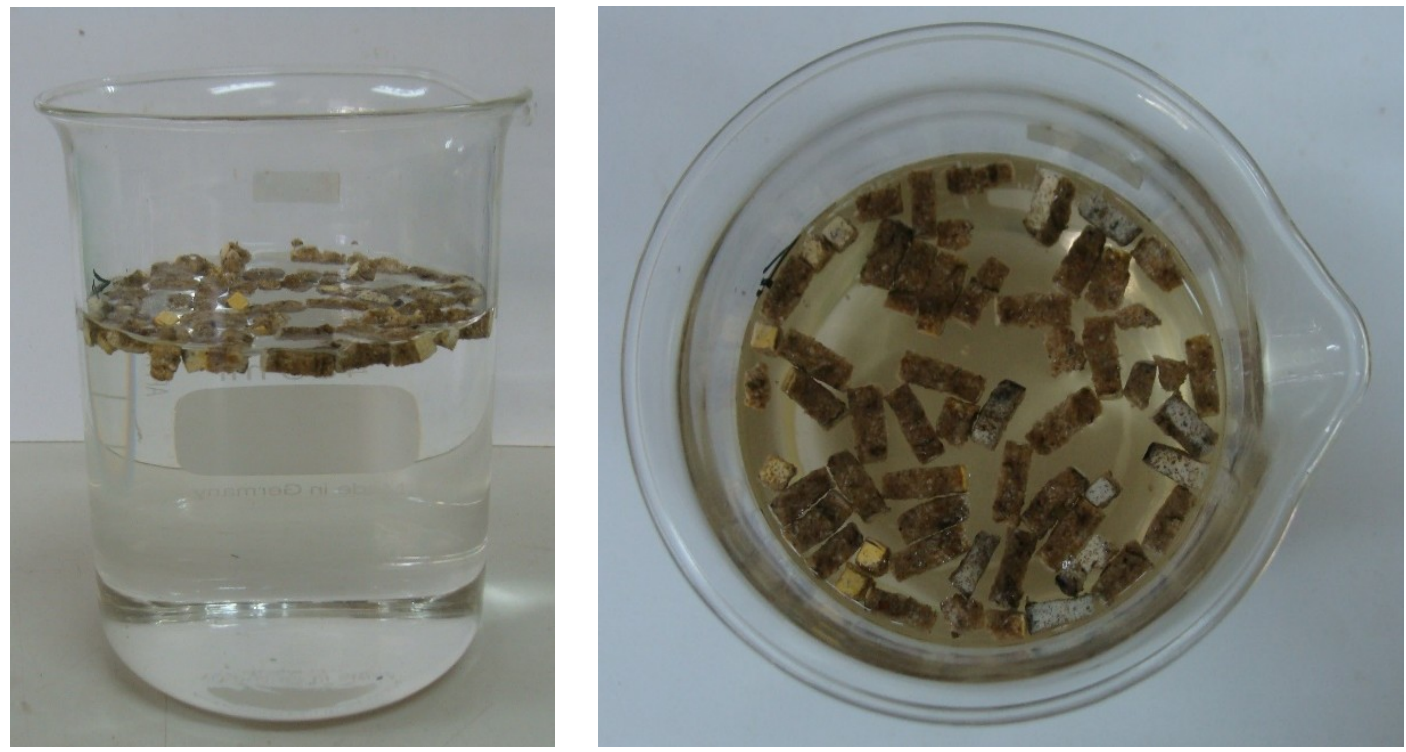

Gambar 3. Pakan apung fermentasi yang telah dikeringkan mampu mengapung pada permukaan air.

pada pakan apung fermentasi mendekati nilai stabilitas dalam air pada pakan apung komersial. Uji ini memberikan kesimpulan bahwa pakan apung dengan bahan onggok, L. minor dan pakan tenggelam yang difermentasi oleh $R$. oryzae tanpa penambahan bahan pengikat khusus dan tanpa menggunakan mesin canggih mampu menyamai tingkat stabilitas dalam air pada pakan apung komersial yang biasa digunakan oleh pembudidaya ikan.

Berbeda dengan pakan untuk ternak, pakan untuk ikan budidaya-memerlukan tahapan-tahapan proses tertentu untuk memastikan bahwa pelet yang dihasilkan memiliki stabilitas yang baik dalam air. Stabilitas ini mesti cukup untuk memberi waktu bagi hewan air untuk menyantapnya. Untuk itu, ekstrusi dengan atau tanpa zat pengikat (perekat) yang menyatukan butiranbutiran komponen bahan pakan ikan diperlukan dalam rangka tetap mengokohkan atau menstabilkan butiranbutiran pakan tersebut agar tidak mudah terurai hancur dalam air, dan memastikan agar sesedikit mungkin zat-zat gizi dalam pakan yang hilang terlarut ke dalam air kolam (Hashim dan Saat 1992; Paolucci et al. 2012).

Zat perekat khusus tidaklah digunakan dalam pembuatan pakan ikan apung dalam eksperimen ini, sebagaimana pada pembuatan pakan komersial yang melibatkan penggunaan zat pengikat yang tergolong karbohidrat seperti agar-agar, alginat, pektin, kitosan, karaginan, karboksimetilselulosa, guargam, maupun dari jenis protein seperti gelatin (Paolucci et al. 2012). Penyatuan butiran-butiran pakan dalam percobaan ini adalah agen hayati berupa miselium kapang tempe, yakni Rhizopus sp., yang sudah dikenal dapat 


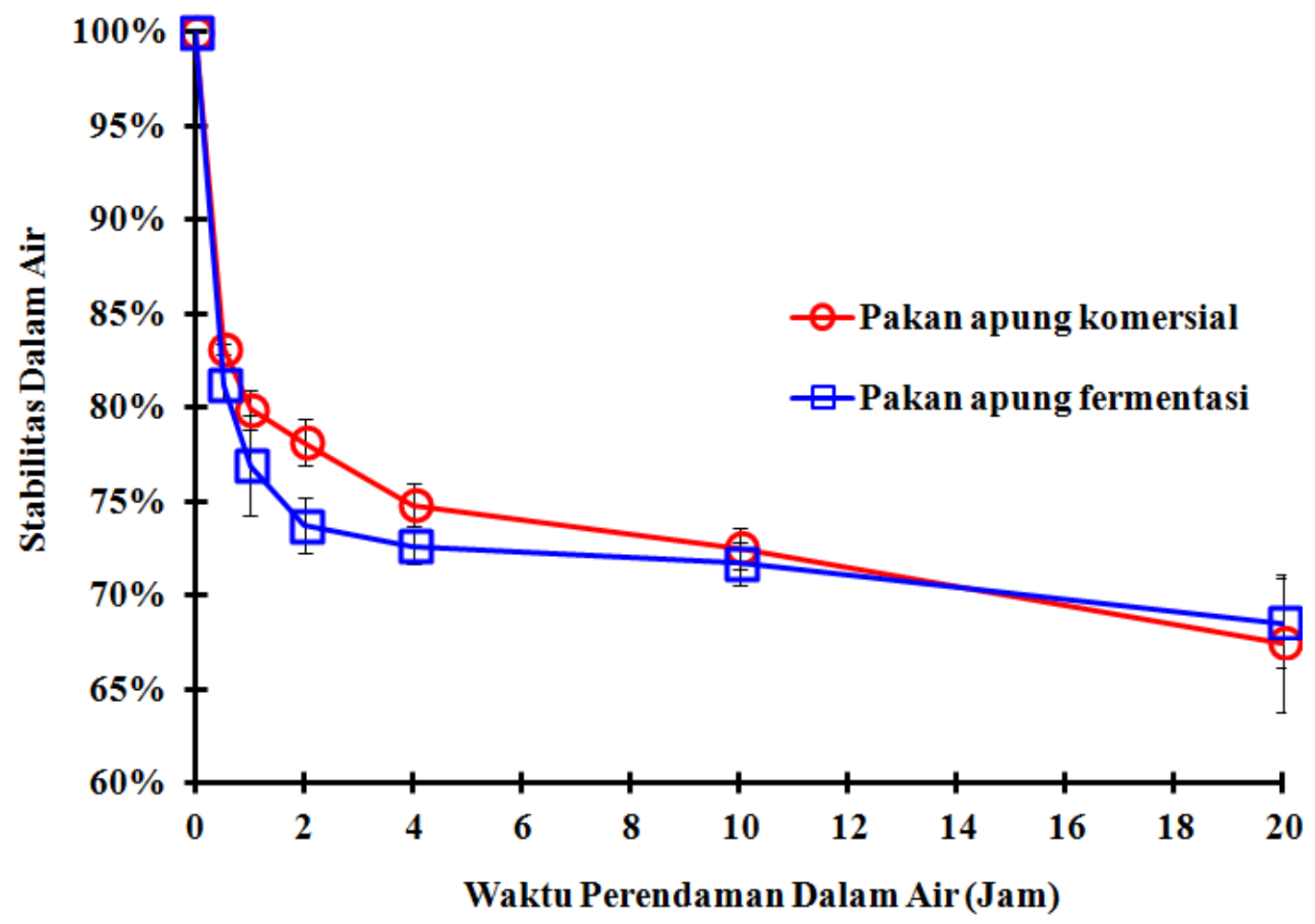

Gambar 4. Stabilitas dalam air dari pakan apung komersial dan pakan apung fermentasi

menyatukan butiran kedelai pada pembuatan tempe kedelai melalui fermentasi pada suhu kamar.

Penggunaan kapang tempe sebagai agen hayati pengikat ini juga menghindari kerusakan nutrisi yang rentan terhadap panas sebagaimana yang terjadi pada proses ekstrusi yang dapat merusak vitamin tertentu (Riaz et al. 2009). Fermentasi Rhizopus bahkan sudah terbukti malah memperkaya vitamin tertentu pada substrat media tumbuhnya (Sriherwanto 2010).

\section{Absorpsi air}

Secara umum, kedua bentuk kurva absorpsi air selama 40 menit untuk kedua jenis pakan sangatlah mirip. Keduanya sangat cepat menyerap air di menit pertama, dimana pakan apung fermentasi sekitar tiga kali lebih kuat menyerap air dibandingkan pakan apung komersial. Proses penyerapan air oleh kedua jenis pakan ini naik tapi dengan kecepatan daya serap yang menurun setelah menit ke-1 hingga menit ke-10. Setelah itu pakan apung komersial tidak lagi mampu menyerap air setelah penyerapannya mencapai sekitar $200 \%$ atau 2 kali bobot kering awal. Di menit ke-10, pakan apung fermentasi mampu menyerap air hingga $361 \%$, yakni hampir 4 kali lipat lebih berat dibandingkan bobot kering pakan tersebut. Namun absorpsi air pakan fermentasi ini menurun di menit ke-20, lalu naik lagi sedikit di menit ke-40. Penurunan ini diduga karena tingkat kekompakan pakan berkurang yang menyebabkan sebagian material pakan tersebut hancur dan meluruh.

$$
\text { Lebih tingginya kemampuan }
$$

menyerap air pakan apung fermentasi dibandingkan pakan apung komersial mungkin dikarenakan volume total rongga udara yang lebih besar pada pakan fermentasi dibandingkan pada pakan komersial. Besarnya volume total rongga udara ini diduga karena hifa kapang $R$. oryzae mampu menembus ke dalam butiran substrat sehingga membuat jalinan loronglorong udara mikro di dalam substrat. Selain itu, miselium kapang memenuhi rongga antar butiran substrat, sehingga memerangkap udara di celah-celah antarsubstrat. Metabolisme nutrisi substrat menjadi senyawa sederhana yang mudah menguap (volatile low molecular weight compounds) juga meninggalkan ronggarongga udara mikro dalam substrat. Tersedianya ruang-ruang udara mikro di sela-sela jalinan padat miselium dan di dalam substrat juga memungkinkan air terserap oleh pakan fermentasi secara lebih 


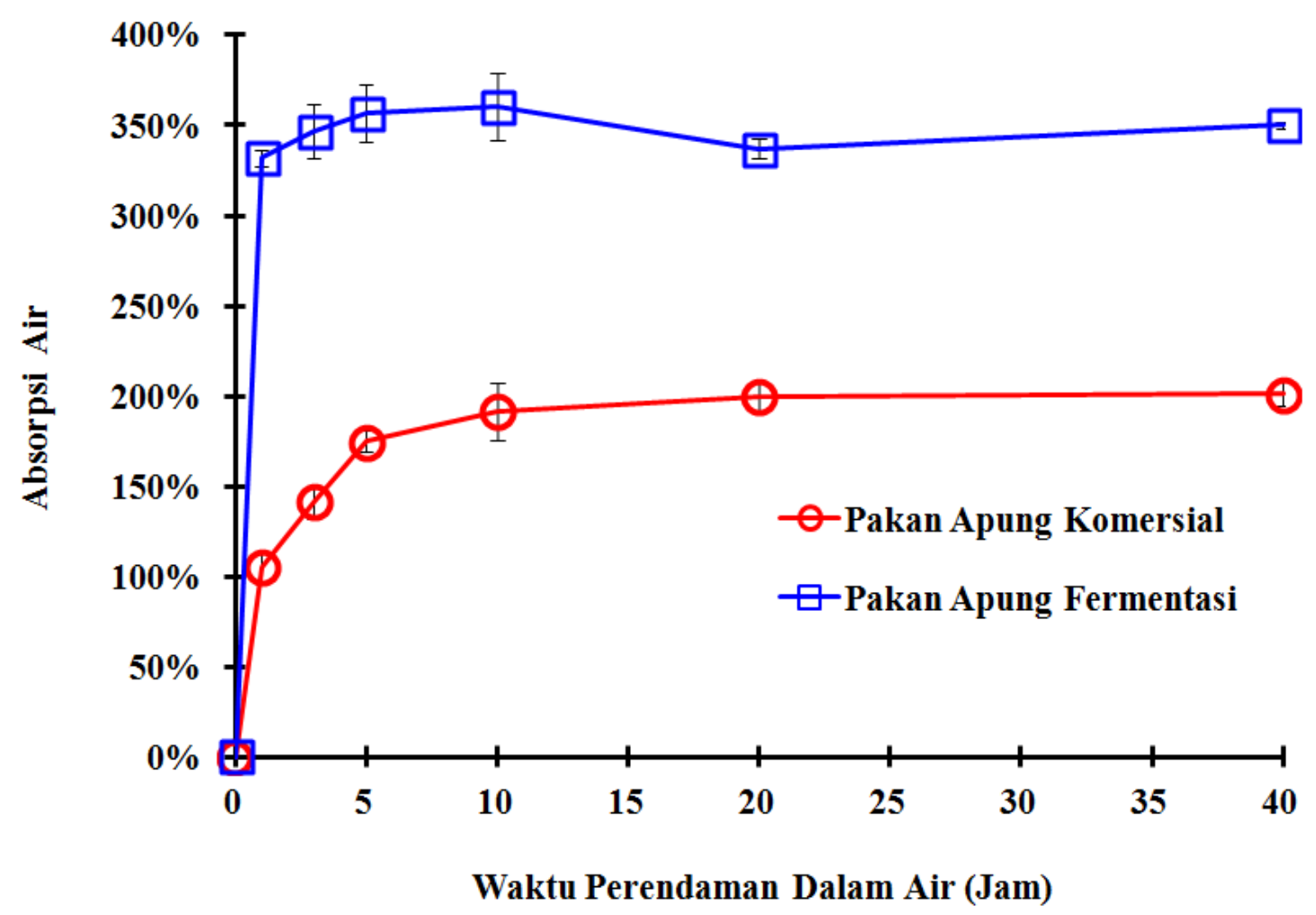

Gambar 5. Absorpsi air pakan apung komersial dan pakan apung fermentasi

cepat dibandingkan oleh pakan komersial saat perendaman dalam air berlangsung.

Keunggulan pada pakan apung fermentasi ini adalah, meskipun nilai absorpsi airnya lebih tinggi, stabilitasnya dalam air setara dengan pakan apung komersial. Pembuatan pelet apung komersial menggunakan mesin ekstruder yang melibatkan tekanan dan pemanasan tinggi, dengan komposisi bahan perekat atau pengikat yang sengaja ditambahkan, seperti zat pati. Bahan-bahan yang terbuat dari pati mampu menyerap air dikarenakan molekulmolekul pati memiliki gugus hidroksil yang dapat membentuk ikatan hidrogen dengan air (Ayadi et al. 2016).

\section{Daya apung}

Gambar 6 menunjukkan bahwa selama tiga jam, baik pakan apung fermentasi maupun pakan apung komersial tidak ada yang tenggelam sama sekali ke dalam air tenang. Hal ini menunjukkan bahwa dalam rentang waktu uji apung selama 3 jam, fermentasi mampu memunculkan daya apung yang setara dengan kemampuan mengapung yang dimunculkan oleh mesin ekstruder pada pakan ikan apung pabrikan. Kemampuan mengapung $100 \%$ dari pakan fermentasi dalam uji selama 3 jam ini lebih lama dibandingkan waktu uji daya apung 20 menit yang dilakukan oleh Kamaruddin et al. (2018). Peneliti tersebut membuat pakan apung yang mengandung talas dan beras yang sebelumnya digelatinisasi menggunakan mesin ekstruder dengan lubang pengeluaran (die) bersuhu $170^{\circ} \mathrm{C}$, dimana daya apungnya selama 20 menit adalah $93,3 \%-100 \%$.

Metode pengapungan non-ekstrusi menggunakan kapang Rhizopus sp. dalam penelitian ini juga memiliki daya apung yang lebih baik dibandingkan teknik non-ekstrusi lain. Pengapungan tanpa menggunakan mesin ekstruder telah dilakukan Orire dan Sadiku (2014) dengan memanfaatkan peran ragi roti (yeast) dan pengembang roti (baking powder). Hasil terbaik yang didapat adalah $70 \%$ masih mengapung pada menit ke-60. Penggunaan ragi Saccharomyces cerevisiae untuk mengapungkan pakan ikan juga dilakukan oleh Saputra (2016) dan Lindasari (2017). Formulasi pakan yang digunakan dalam kedua penelitian tersebut memasukkan terigu $35 \%$ sebagai bahan perekat dan menggunakan tahapan deep frying atau penggorengan dalam minyak. 


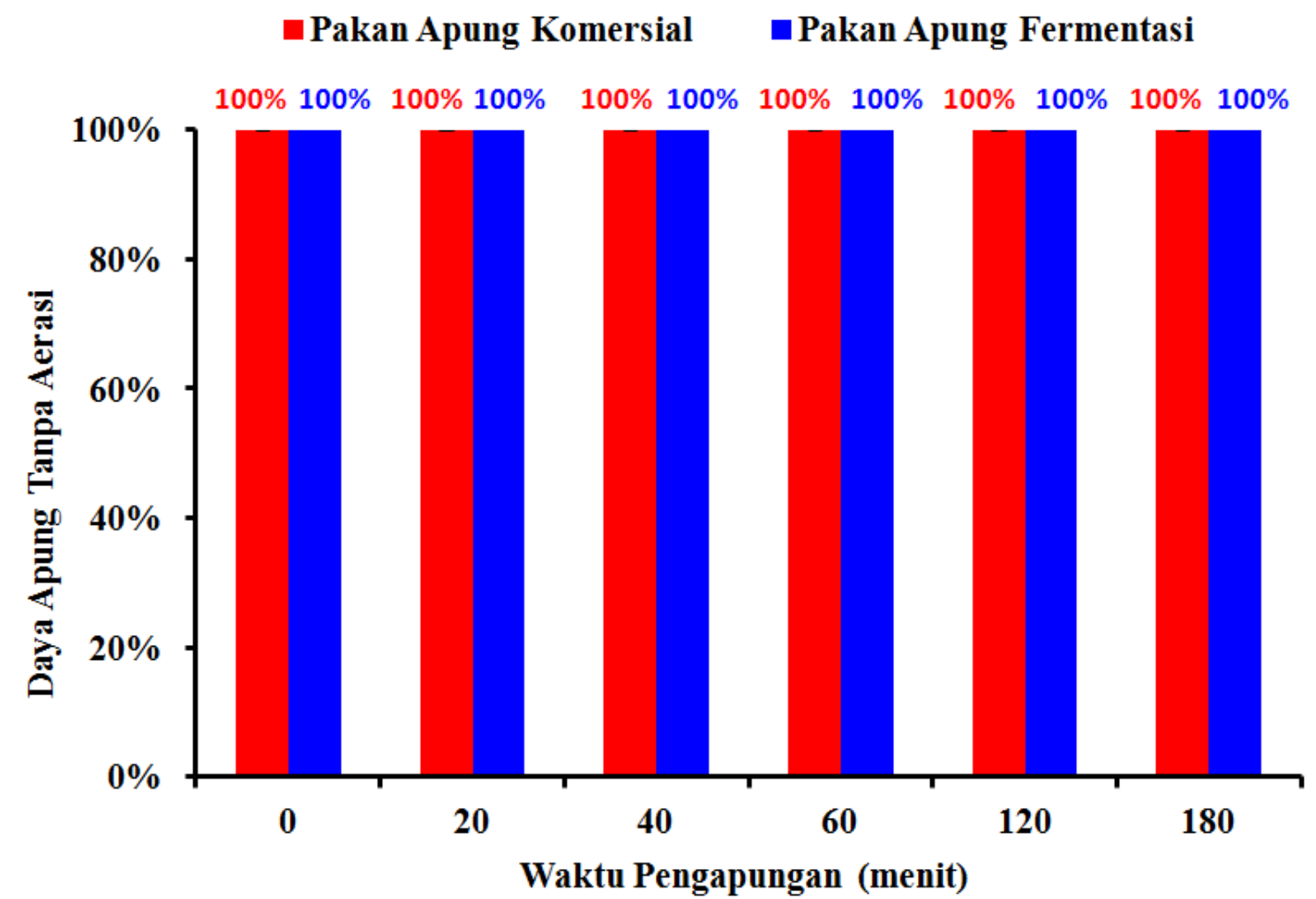

Gambar 6. Uji daya apung pakan apung komersial dan pakan apung fermentasi tanpa aerator

Pakan ikan yang dihasilkan mampu mengapung selama 6-8 jam. Proses pemunculan sifat apung pada pakan ini kurang efisien dibandingkan dengan yang dilakukan dalam penelitian ini, yang tidak perlu mempertimbangkan penambahan zat perekat, dan tanpa penggorengan dalam minyak yang memerlukan tambahan ongkos energi, bahan, dan sarana produksi lainnya.

\section{KESIMPULAN}

Fermentasi substrat campuran pakan tenggelam komersial, onggok, dan gulma bebek menggunakan kapang $R$. oryzae memunculkan sifat apung pada produk hasil fermentasinya. Saat dibandingkan dengan pakan apung komersial, pakan apung fermentasi ini memiliki pola kurva stabilitas dalam air yang mirip dengan pakan apung komersial selama 20 jam dalam air. Stabilitas keduanya sama-sama mengalami penurunan drastis pada 30 menit pertama, dari $100 \%$ turun hingga ke $81-83 \%$. Demikian pula dengan bentuk kurva absorpsi air selama 40 menit pengujian, kedua jenis pakan tersebut memperlihatkan sifat fisik penyerpan air yang sangat mirip. Pakan apung fermentasi menyerap air hampir 4 kali berat kering awalnya, sedangkan pakan apung komersial hingga sekitar 2 kali berat kering awalnya. Selama tiga jam pengujian daya apung, kedua jenis pakan mengapung $100 \%$ tanpa satu butir pelet pun yang tenggelam. Jadi, fermentasi bahan pakan ikan menggunakan $R$. oryzae layak dikembangkan lebih lanjut sebagai cara pengapungan alternatif pakan ikan agar karakteristik fisiknya semakin baik dan mendekati pakan apung ekstrusi.

\section{REFERENSI}

Ayadi F, Rosentrater KA, Muthukumarappan K, Kannadhason S (2016) Effects of Amylose-to-amylopectin ratios on binding capacity of DDGS/soy-based aquafeed blends. J Food Res 5:43. doi: 10.5539/jfr.v5n5p43

De Cruz CR, Kamarudin MS, Saad CR, Ramezani-Fard E (2015) Effects of extruder die temperature on the physical properties of extruded fish pellets containing taro and broken rice starch. Anim Feed Sci Technol 199:137-145. doi: 10.1016/j.anifeedsci.2014.11.010

Dirjen Perikanan Budidaya (2016) Harapan 
pada bantuan pakan mandiri. akuakultur indonesia 24:7

Erizal E, Lana M, Setyo R, Abbas B (2016) Sintesis dan karakterisasi hidrogel superabsorben berbasis asam akrilat hasil iradiasi gamma. J IIm Apl Isot dan Radiasi 11:27-38. doi: 10.17146/jair.2015.11.1.2697

Hashim R, Saat MAM (1992) The utilization of seaweed meals as binding agents in pelleted feeds for snakehead (Channa striatus) fry and their effects on growth. Aquaculture 108:299-308. doi: 10.1016/0044-8486(92)90114-Z

Kamarudin MS, de Cruz CR, Saad CR, Romano N, Ramezani-Fard E (2018) Effects of extruder die head temperature and pre-gelatinized taro and broken rice flour level on physical properties of floating fish pellets. Anim Feed Sci Technol 236:122-130. doi: 10.1016/j.anifeedsci.2017.12.007

Kurniawan A, Lestariadi RA (2017) Induction of fish pellet making machine to improve feed community program in catfish farmers in mojokerto regency. $\mathrm{J}$ Innov Appl Technol 3:433-438. doi: 10.21776/ub.jiat.2017.003.01.16

Leiskayanti Y, Sriherwanto C, Suja'i I (2017) Fermentasi menggunakan ragi tempe sebagai cara biologis pengapungan pakan ikan. J Bioteknol Biosains Indones 4:54-63. doi: 10.29122/jbbi.v4i2.2503

Ljøkjel K, Sørensen M, Storebakken T, Skrede A (2004) Digestibility of protein, amino acids and starch in mink (Mustela vison) fed diets processed by different extrusion conditions. Can J Anim Sci 84:673-680. doi: 10.4141/A01-089

Lindasari A (2017) Pembuatan pakan terapung terfermentasi Saccharomyces cerevisiae melalui proses non-ekstrusi. Undergraduate Thesis. Bogor Agricultural University

Misra CK, Sahu NP, Jain KK (2002) Effect of extrusion processing and steam pelleting diets on pellet durability, water absorption and physical response of Macrobrachium rosenbergii. ASIAN Australas J Anim Sci 15:1354-1358. doi: 10.5713/ajas.2002.1354
Orire AM, Sadiku, SOE (2014) Development of farm made floating feed for aquaculture species. J Int Sci Publ: Agriculture dan Food 2:521-523

Paolucci M, Fabbrocini A, Volpe MG, Varricchio E, Coccia E (2012) Development of biopolymers as binders for feed for farmed aquatic organisms. In: Muchlisin Z (ed) Aquaculture, InTech, Rijeka, Croatia, pp 3-34. http://cdn.intechweb.org/pdfs/ 27101.pdf. Accessed 10 October 2017

Rana KJ, Siriwardena S, Hasan MR (2009) Impact of rising feed ingredient prices on aquafeeds and aquaculture production (No. 541) (p. ix). Food and Agriculture Organization of the United Nations (FAO)

Rasidi R, Haryadi J (2016) Evaluasi kebijakan pengembangan pakan mandiri. In prosiding forum inovasi teknologi akuakultur 1:689-702

Riaz MN, Asif M, Ali R (2009) Stability of vitamins during extrusion. Crit Rev Food Sci Nutr 49:361-368. doi: 10.1080/10408390802067290

Saputra RA (2016) Uji kualitas fisik pakan terapung terfermentasi Saccharomyces cerevisiae melalui proses non-ekstrusi dan deep frying. Undergraduate Thesis. Bogor Agricultural University

Somerville C, Cohen M, Pantanella E, Stankus A, Lovatelli A (2014) Fish in aquaponics. In: Small-scale aquaponic food production: integrated fish and plant farming, FAO Fisheries and Aquaculture Technical Paper No 589 (pp. 103-121). Food and Agriculture Organization of the United Nations, Rome

Sriherwanto C (2010) Studies on the solid state fermentation of cassava bagasse for animal feed. Doctoral Thesis, Department of Chemistry, University of Hamburg, Germany

Sriherwanto C, Suja'i I, Soraya S (2017) Pemanfaatan kapang Rhizopus sp. sebagai agen hayati pengapung pakan ikan. J Mikol Indones 1:70-81

Van Rooijen C (2016) Effect of extrusion conditions on the Maillard reaction and in vitro digestibility in two dry dog foods. In: Maillard reaction products in pet foods. PhD Thesis. Wageningen University 